看護研究報告：

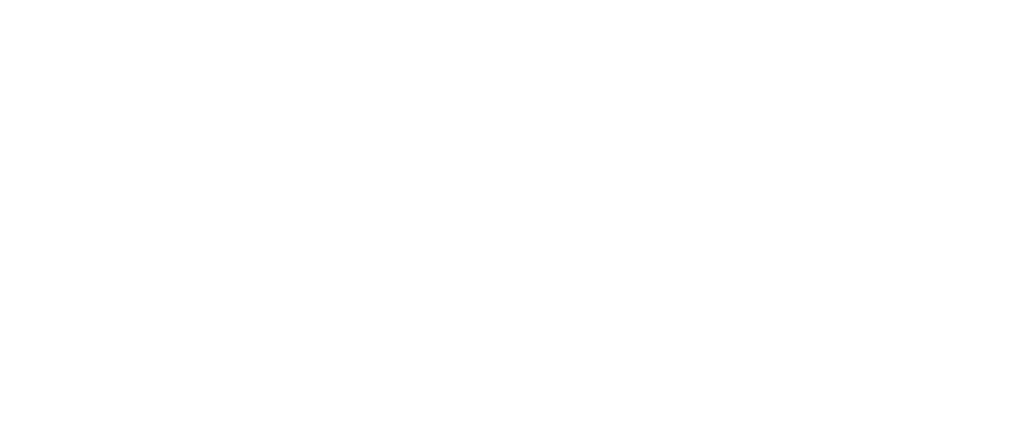

$$
\text { I.は じめに }
$$

当院で分婏される方の希望や思いに添った援 助をより深めたく, 平成14年 4 月よりバース・ プラン (以下 B・P と略す) を導入した(表 1 )。特に，分婏目的で入院された産婦とは初 対面のことが多く(外来との連携不足もあっ た，光の方の希望や考えがはっきりとわから ないまま分婏が進み，満足した分婏が出来たの か , 私たちの関わりはこれでよかったのか疑問 を抱き始めたからであった。妊娠32週の妊婦健 診時にバース・プランの用紙を渡し, 次回の来 院時に提出してもらい確認し合った。さらに， 入院時担当助産師が再度確認し, 希望をくみ取 りながら妊産婦と関わっていった。記載内容に は「よろしくお願いします・特にない・初めて なのでわからない」など，具体的なプランを持 つ方は少なく，受身的な内容が多いと感じてい た。しかし，安部氏らによる報告で“自分で 産むという意識が薄く依存的である”といった 産む人に対する否定的な感情が病院に勤務する 助産婦 (現助産師) に多く見られる」文と, 病 院側の問題か指摘されていることを知った。同 時に私たちは, もつと妊産婦の声を聴く努力が 必要であったと気づいた。

弚こで今回, 私たちの思いから始めた B・P が, 分婏された方たちにどの樣に捉えられてい

\footnotetext{
\% 044-0001 北海道虻田郡俱知安町北一条東1 俱知安厚生病院産婦人科

(受付 : 2003年12月 3 日)
}

たのか明らかにする為アンケートを実施した (表 2 )。炎の結果を報告する。

$$
\text { II. 研 究 方 法 }
$$

調査期間 : 平成14年12月～平成15年 3 月。 調査対象: 当院で分婏した裖婦 (帝王切開, 死産，早産を除く) で，1 健診で来院した 際，研究の主旨を説明し協力を得られた100 名。

調査方法 : 質問紙を作成し（質問形式は選択 回答と自由回答の混合方式とした），産婦人科 外来において，1 か月健診の待ち時間に質問紙 を配布し，無記名とし回収した。

調査内容: 対象の背景 (年齢, 出産経験, 母 親学級受講の有無，B・P の有無）と B・P に関 連した 8 項目，分婏に対する満足度等。

分析方法 : 単純集計・自由回答はKJ 法でま とめた。

$$
\text { III. 結果 }
$$

対象者100名のうち, 初産婦は42名, 経産婦 は58名であった。母親学級の受講者は初産婦27 名 $(64 \%)$ ，経産婦 6 名 (11\%) であった。バー ス・プラン有りは初産婦39名 (93\%)，経産婦 50名 (86\%) であった (図 1 )。

バース・プラン提出者89名について

「バース・プランを記入するにあたり，何か 参考にされましたか」の問いに対して (複数回 答)，特にないと答えた人は69名 $(78 \%)$ ，本・ 杂隹誌が12名 $(14 \%) ， 母$ 親学級が 8 名（８％)， 
表1 . バース・プラン用紙

$$
\text { 私のバース・プラン }
$$

お名前

出産予定日 月 日

1 . ご自分が母親になることや, 出産についてどんな印象をお持ちですか?

今までお聞きになった，またはご自身の経験をもとにお書きください。

助産師記入

2.どんなお産がしたいとお考えですか？ また，何かご希望がありますか？

3.お産の時, 助産師に何を望みますか?

4. 育児 (母乳保育) の方針についてのご希望があればお書きください。

5 . 退院後はどちらに戻られますか?

自宅 実家 夫の実家 弚の他（）

6 . 退院後のお手伝いの主力はどなたですか?

夫両親 夫の両親弚の他（）

(こ記入されましたら，来院の際，産婦人科外来スタッフにお渡しください。) 
表 2 .「バース・プラン」アンケート

ご出産後，1 ヶ月が経ちましたがお母樣と赤ちゃんの健康状態は順調なことと思います。今回，ご 出産前に皆樣にお願いした「バース・プラン」についてお尋ね致します。

1.あなたの年齢をお答えください。

～19歳 20 24歳 25 29歳 30 34歳 35 39歳 40歳

2.お産は初めてでしたか?

はい いいえ（回目)

3. 当院での母親学級を受講されましたか?

はい いいえ（回目)

4 .お産前にバース・プランを提出されましたか?

はい いいえ（回目）

5 . 4で「いいえ」とお答えされた方にお伺いいたします。光の理由に該当するもの1つに○をつけ てください。(弚の後, 次ページの7から回答をお願いいたします。)

・用紙をもらわなかった（知らなかった）から

・提出するのを忘れた（または紛失した）から

・提出する前に産まれたから

・何を書いていいかわからなかったから

• その他 (

6.4 で「はい」とお答えされた方にお伺いいたします

(1)バース・プランを記入するにあたり，何か参考にされましたか？ 該当するものに○をつけてく ださい。

特にない 本や雑誌 母親学級 弚の他（）

(2)バース・プランを記入するにあたり，相談した相手はいましたか？ 該当するものに○をつけて 下さい。

特にいない 夫 (パートナー) 親 友人 姉妹 助産師

兴の他（）

(3)バース・プランを提出する時期について, どう思われますか?

早すぎる ちょうど良い＼cjkstart遅すぎる

光の他（ 
(4)バース・プランを提出された後，何か努力されたことがあればお書きください。

(例えば「安産のために体重の増えすぎに気をつけた」など)

[

(5)バース・プランは役に立ちましたか？

・役に立った (弚の理由 :

・役に立たなかった（弚の理由：

(6)バース・プラン通りにお産が進みましたか?

・はい

・いいえ（弚の理由：

(7お産の際，担当助産師はあなたのバース・プランについて確認しましたか?

・はい

・いいえ（光の理由：

８また，担当助産師はあなたに，十分な配慮をしてくれましたか?

・はい

・いいえ（光の理由：

7 . 今回のお産の満足感はいかがですか? 該当するもの1つに○をつけてください。

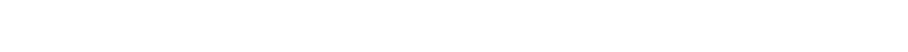

8.7 で「不満」とお答えされた方はぞの理由をお書きください。

[

9 . 次回のお産の際には , バース・プランを提出したいと思いますか?

・はい(光の理由 :

・いいえ（光の理由：

お忙しい中，アンケートにこ協力くださりありがとうございました。皆樣の貴重なこ意見を今後の 参考にさせていただきます。尚，産婦人科外来・産婦人科病棟に対してこ意見・ご要望等ございまし たらご自由にお書きください。 
谷の他として,「前回の出産を参考にした, 友 人に聞いた，夫が学生時代に学んだことを基に 書いた」という声があった (図 2 )。

「バース・プランを記入するにあたり，相談 した相手はいましたか」の問いに対して(複数 回答)，特にないと答えた人は57名 $(64 \%)$ ， 夫・パートナーが28名 (31\%)，親 4 名 (3\%)， 友人 2 名 ( $2 \%)$, 助産師 1 名 (1\%) であつ た (図 2 )。

「バース・プラン」を提出する時期につい て、「どう思われますか」の問いに対して，ちょ うど良いがもっとも多く83名 (93\%)，遅すぎ るが 2 名 ( $2 \%)$, 早すぎるが1名 (1％)，光 の他 3 名 ( $3 \%)$ で, 兴の中で「里帰りなので
提出が遅くなるのは仕方がない」という声が あった (図 3 )

「バース・プランを提出された後, 何か努力 されたことがあればお書きください」の自由回 答に対しては，「体重や食生活に気をつけた， 歩くことや休息をとるように心がけた，安産体 操，呼吸法の練習，ゆったり過ごすようにし た」などの声があった。

「バース・プランは役に立ちましたか」の問 いに対して，役に立ったと答えた人は65名 (73\%) で，光の理由として，「具体的に考え る機会になったから，聞きたいこと等を出産前 に教えてくれたから，バース・プラン通りにし てくれたから，書くことで整理ができたから」

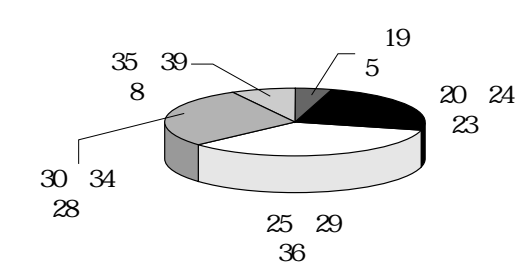

当院の母親学級受講の有無

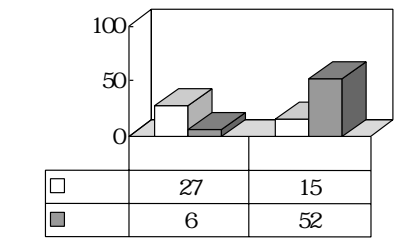

お産の回数 (人数)

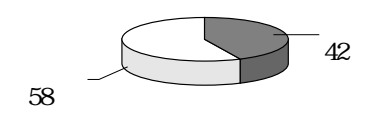

バースプランの提出有無

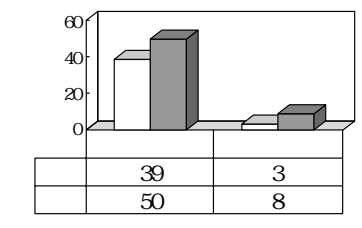

図 1 . 結果 (対象の背景) $n=100$

記入にあたり参考にしたもの

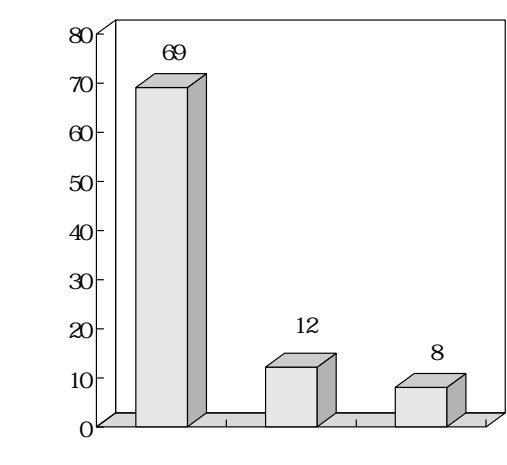

記入時の相談相手

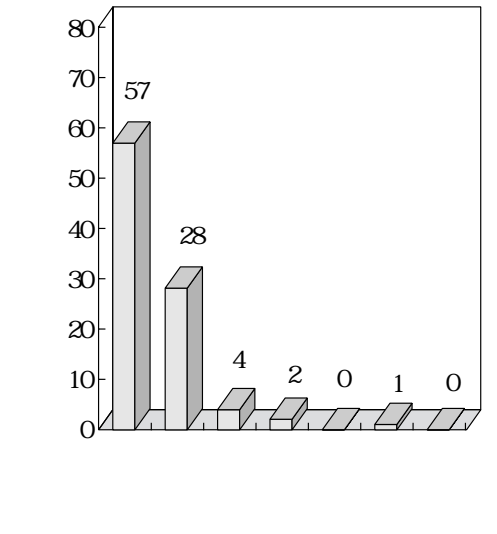

図 2 .結果 (バース・プランについて) 
などの声があった。また，役に立たなかったと 答えた人は13名 $(15 \%)$ で,「頭の中になかっ たから，夫に立ち会って欲しかったが出来な かったから, 分婏前にもう一度確認し合いた かったから」などの理由があげられていた。無 記入は11名（12\%) であった（表 3)。

「バース・プランに書いたような出産ができ ましたか」の問いに対して, はいと答えた人が
65名 (73\%)，いいえが21名 (24\%) であった。 いいえと回答した理由は，「思っていたより出 産に時間がかったから，呼吸法がうまくでき なかったから，予定日より早く生まれ心の準備 ができていなかったから」などの声があった。 無記入は3名 (3％) であった。

「出産の際，助産師はあなたの B P P につい て確認しましたか」の問いに対して,はいと答
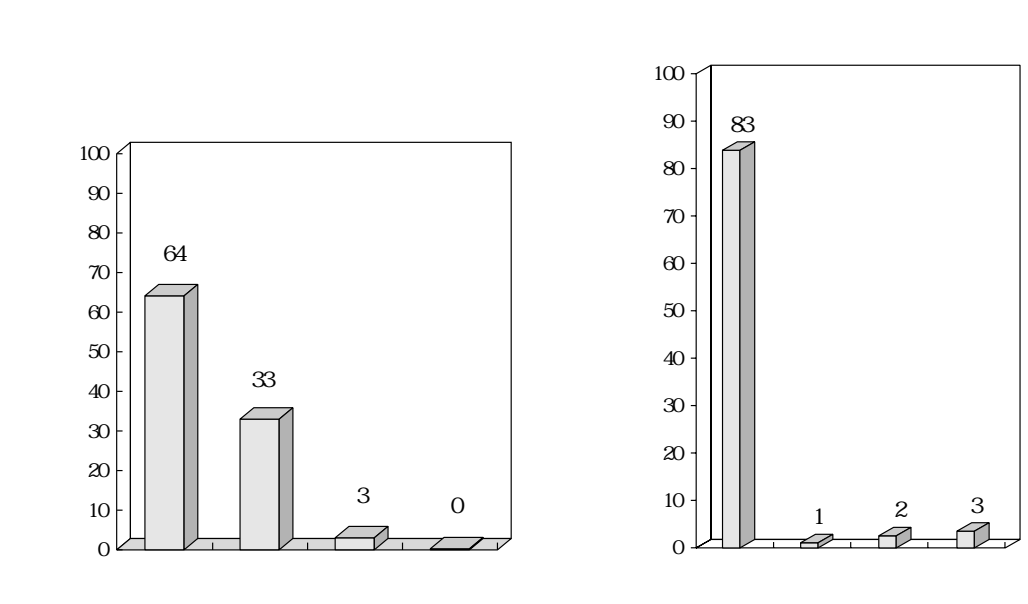

図 3. 結果 (出産満足度 $\cdot$ 時期)

表 3 . 結果 (B・P は役立ったか? )

一役立った (自由回答)

・体重管理に気をつけたから

・食生活に気をつけたから

・なるべく体を動かすようにしたから

バースプランは役立ったか

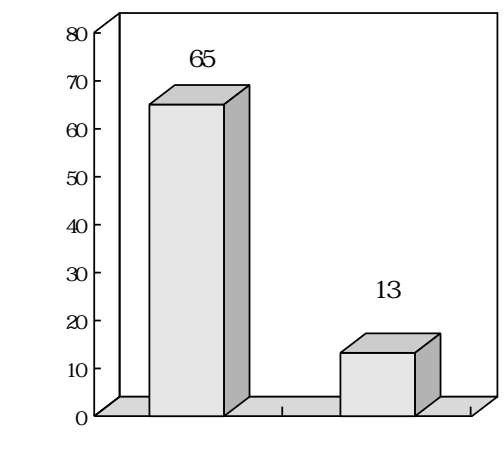

・医師の指示や母親学級で習ったことを心がけたから

·具体的に考える機会になったから, 出産に向けての自覚が明確に なったから，心の準備ができたから

・聞きたいことを出産前に教えてくれたから

・バースプラン通りにしてくれたから

・気持ちが楽になった，不安なくお産に臨めたから

・いいお産だったから

・希望を伝えられたから，妊婦側と病院側との意思疎通が図れたと 感じたから

・一人目の時より自分に合ったお産ができたから

役立たなかった (自由回答)

・ 中毒症になったので役に立たなかった

・何を書いたのか忘れてしまったから

・出産前にもう少し助産師と話ができたらと思ったから

・二人目だったのであまり考えなかったから

・夫に立ち会ってほしかったができなかったから

・予想以上に痛くて光れどころではなかったから

・車の中でのお産だったから 
表 4 . 結果 (次回出産時 B P P 提出希望)

次回の出産の際にバース プランを提出したいと思うか

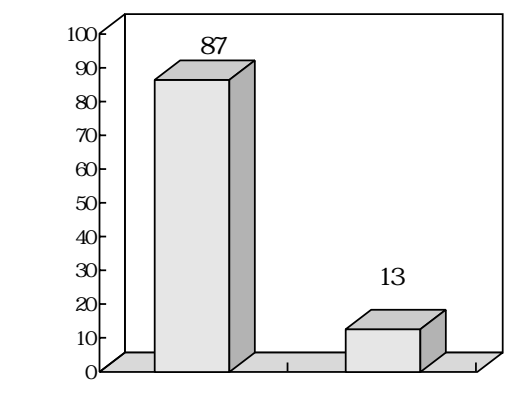

・はい (自由回答)

·夫立会い出産を次も望んでいるから

・満足のいくお産に協力してもらえるから

・自分の考えを助産師も理解してくれると思うから

·自分なりの出産ができると思うから

・今回希望どおりの出産ができたから

·前回を思い出すことができていいから

·今度こ光プランどおりになればいいと思うから

・お産の流れのイメージにつながるから

・次回はゆっくりと考えてみたいから

・自分の考えをわかってもらった上でのお産が大切だと思うから

・口頭ではうまく伝えられないから

-いいえ (自由回答)

・こんなお産がしたいというこだわりがないから
えた人が63名 (71\%)，いいえが21名（23\%）， 無記入 5 名 (6\%) であつた。

「担当助産師はあなたに，十分な配慮をして くれましたか」の問いに対して, 全員「はい」 と答えていた。

今回の出産の満足度について, 対象者100名

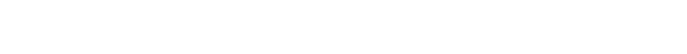

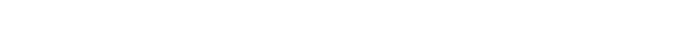
かといえば不満」が2名（2％) であった (図 3 )。

次回の出産に対して,「バース・プランを提 出したいと思いますか」の問いに対して，はい と答えた人は85名 $(85 \%)$ で, 兴の理由として

「自分の考えを理解してもらいたいから，希望 通りの出産ができたから, どの子も心を込めて 産みたいから」などの声があった。続いて，い いえは13名 (13\%) で「こんなお産がしたいと 言うこだわりがないから」という声があつた。 無記入は 2 名 (2％) であった (表 4 )。

$$
\text { IV.考察 }
$$

$\mathrm{B} \cdot \mathrm{P}$ の提出率は導入当初 $40 \%$ であったが， 現在では89\% (図 1) と高くなった。これは， 妊娠初期に渡すパンフレットにB・P の項目を 付け加えたこと, 母親学級や両親学級の中で $B \cdot P$ に対する説明を取り入れ, 妊娠後期には B・P の確認を行ったことにより広まったと考 える。又，B・P を記入するにあたり，31\%の
方は「夫やパートナーに相談した」(図 2 ) と 答えており, 妊娠を取り巻く家族とのコミュニ ケーションをとる必要性を再確認した。

$\mathrm{B} \cdot \mathrm{P}$ を提出した後には, 自分 (たち) で考 えた出産に向けて,さまざまな取り組みや努力 をしていたことがわかった。B・P を記入する ことにより，自分らしい出産を考え，弚の実現 のために, 妊婦自身の行動に変化がみられたこ とはとても意義があると考える。光れは，「主 体性を認めることが自分らしく出産できる第一 歩であり，光の主体性を具体的に表現したもの がバース・プランである」光といわれているよ うに, B・P記入により，自分の意思と判断に 基づいた行動へと繋がっていったと考える。

「出産の際, 助産師が B・P の確認を行った か」の問いでは「はい」が71\%と低かった。又， $B \cdot P$ 提出後, 助産師との話し合いを希望して いた方がいことがわかった。B・P を導入す るまで, 外来助産師は妊婦と関わり, 病棟助産 師は産裖婦と関わる，というように，当院助産 師の妊産婦のケアは断片的であった。特に，陣 痛が発来し，入院された時，分婏に対する意思 や考えを引き出す難しさを日々感じていた。 $\mathrm{B} \cdot \mathrm{P}$ は「健診からずっと同一人物による継続 ケアが可能であれば, 文書にする必要性は薄ま る」文といわれているように, 弚の作成過程が いかに重要であるか思い知らされた。今後は， 提出された B・P を基に, 妊婦と助産師が話し 
合える，時間の確保が急務であることが明らか になった。光して，当院にB・P を導入して 1 年を迎えるが, 妊産婦のケアに継続性をもたせ るために, 周産期に関わるスタッフ自身が B ・ P の内容を把握し, 連携を密にしていくことが 必要であると考える。「産む人の側に立ってお 産を考えることがこれまであまりされてこな かった。産む人の希望の実現に重要な意味を見 出す専門家があまりにも少ないのである。」 と あるように, B・Pの活用は妊産婦の視点にた ち, 妊産婦に寄り添い, より近づくことを可能 にするものと確信することができた。又，当院 は西後志管内において, 産婦人科を有する唯一 の総合病院である。現状に甘んじることなく， 選ばれる病院となるよう妊婦のニーズの把握に 努めていきたいと考える。

今回の出産に対して，「どちらかといえば満 足」も加えると，「満足」と答えていた方は97\% と高かった。しかし，「どちらかといえば不 満」と答えた方の中には, 分婏の経過中, 予想 外の体験により思い描いていた分婏とのギャッ プから，分婏が不満足な体験に終わっていた。 弚のため, 現在, 取り入れているバースレュー によりフィードバックを行い, 思いの違いを把 握し, 修正していくことが改めて大切であるこ とを認識した。「周産期の問題は虐待に移行す る大きなファクター」1)といわれている。妊産 婦の声に耳を傾け, 共有し, 弚の後の育児や人 生の自信に嗦がるよう, 関係性を深めていくこ とが重要である。

次回出産時, B・P の提出希望される方は 87\%であった。光の理由には, 表 2 にあるよう に自分の考える出産が出来るように, 助産師と の話し合いを通して，実現させたいという思い が感じられた。しかし，「こんな出産がしたい というこだわりがないため，B・P の必要はな い」と考えている方もいた。このような考えも あるということを受け止め, 決してこちらの考 えを押し付けず, 光の人の持つ考えを引き出し ながら，信頼関係を築き，光の人らしいB・P となるよう支持・支援していきたいと考える。 提出時期に対しては「里帰り分婏で $B \cdot P$ の
提出は遅くても仕方がない」という意見があっ た。今後は「どこにいても同じ医療が受けられ るように」妊婦が自分の作成した B・Pをもつ て里帰りが出来るよう, 施設内助産師同士の連 携も視野に入れた活動が期待されていると考え る。

「助産婦 (現助産師) の仕事を考えること は，私たちにとって“お産とは何か”を問う こととほとんど同じ事。助産師が本来の仕事を 十分にできる環境の整備こ光，私たち産む人の “もっと人間らしいお産を”という願いに深く つながるもの “"助産師の未来は私たちの未 来”，光のように考えるから。坫とあるよう に，貴重な出産体験をお互いがよりよいものと なるように，さらに正常妊産裖婦に対して，責 任をもって継続的なケアができるよう努力して いきたいと考える。

$$
\text { V.まと め }
$$

本調査により，以下のことが明らかになった。 1. B P P は妊婦の声にならない声を引き出 し，分婏に対する考えや思いを知ることに 有効である。又, 妊産婦と信頼関係を築く ために有効である。

2 . 継続性ケアの提供が必要であり, 病棟と外 来の連携強化や助産師外来の開設など，体 制作りが急務である。

$$
\text { 参考・ 引用文献 }
$$

1 ) 日本看護協会. 1992年病院勤務助産婦の業務と役 割に関する調査, 看護白書.日本看護協会出版会, $1993,168-170$.

2 ) 日本看護協会. 大学附属病院におけるバース・プ ランの有効性.第29回母性看護集録 1998：45一 47.

3) 有森直子 . バース・プラン一出産という舞台の台 本. 助産婦 $1996 ; 50(1)$.

4 ) 戶田律子、解説バース・プラン.ペリネイタルケ ア夏季増刊号 .メディカ出版, 1996, 78-79.

5 ) 母性衛生学会. 平成13年集録, バース・プランの 効果と問題点, 第42巻 4 号.

6 ) Moria Groat: The Value of a Birth Plan, Nursing RSA, 7 (9), p. 24, 1992.

7 ) 安部真理子. 産む側2 200人か語る.お産って何だ ろう「グループ・きりん」のアンケート報告 $2002 ; 72: 219$. 
8 ) 佐藤郁夫。「健やか親子21」運動に寄せて .ペリネ イタルケア .メディカ出版, 2003.

9 ) 大田すみこ，他. 北海道看護協会ニュース， No 47,2003 .
10）塩塚幸彦 .ニーズに応えるサービス．周産期医学 2002 ; 32 (増刊号) : 318-321.

11）坂井聖二 . 周産期の母親への援助 . 社会福祉法人 子どもの虐待防止センター, 1996 .

\title{
Outcomes of birth plan
}

_ How did women who gave birth feel about birth plan?

\author{
YaekoISHIKAWA* and Risako KINO*
}

\section{Insroduction}

We introduced a birth plan (BP) in April 2002 for better midwifery in compliance with each parturient woman's wishes and feelings in our hospital. Since then we have felt that few express a concrete idea in the self-administered BP and that most ideas are passive. Abe et al., however, pointed out a problem with hospital midwifes who think often negatively that parturient women are dependent with little awareness of their own childbith. As we realized we had to make more efforts to listen to parturient women, we conducted a questionnaire survey to investigate what they had thought of the BP. The results are described below.

Method

A questionnaire survey was conducted on 100 women who had given birth in our hospital and visited us for postpartal examination one month after childbirth during the period from December 2002 to March 2003, with a recovery rate of $100 \%$.

Result and Discussion

Of the respondents, 31\% said that they discussed their BP with their husband or partner. This confirmed the necessity for pregnant women to communicate with their family. It was revealed that they made every effort in preparation for childbirth after drawing up their BP. Thus, the BP appeared to have induced changes in parturient women's behaviors, serving as the first step for childbirth preparation right in character for them.

The survey also found that $15 \%$ thought the BP useless. One of the reasons given was that they wanted to talk more with their midwife before childbirth. This indicated clearly that maternity care by the midwives in our hospital leaves much room for improvement.

On the other hand, $85 \%$ wanted to submit BP next time. The main reason they cited was that they want to discuss with their midwife their wishes about childbirth. $A$ few said they thought that BP is not necessary because they don't have any special wishes about childbirth. Although this responce is understandable, we will discuss 
with such women how to develop a reliable relationship with them and give supports and assistance to them in making childbirth satisfactory.

One-year use of BP has made it clear that the staff responsible for perinatal care should understand each parturient's BP and cooperate more closely with the parturient. It was clearly shown that the effective use of BP could help us understand parturients' points of view and fulfill their wishes as much as possible. We will try to grasp their needs so that we, as the staff of the only general hospital with the obsterics department in the Nishi-shiribeshi area, can live up to their expectations.

Conclusion

1. The BP effectively helps us elicit parturients' inner voice and know their thoughts and wishes about childbirth.

2. It is necessary to provide continuous care ; there is a pressing need to develop a system by strengthening cooperation between the inpatient ward and the outpatient clinic and setting up the outpatient maternity department.

*Kucchan-Kose General Hospital, Hokkaido Prefectural Federation of Agricultural Cooperatives for Health and Wedfare, Hokkaido, J apan 